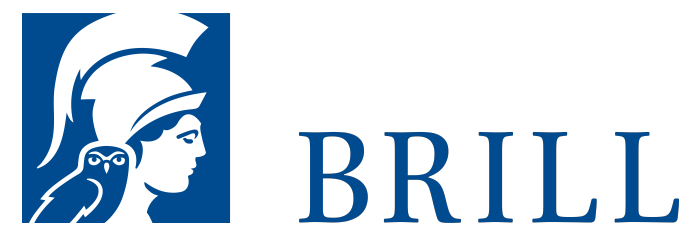

\title{
Masse lesen, Masse schreiben
}

Eine Diskurs- und Imaginationsgeschichte der Menschenmenge 1765-1930

\section{Author: Michael Gamper}

Die Menschenmasse gehört seit dem ausgehenden 18. Jahrhundert zu den verstörendsten Phä-nomenen der westlichen Welt. Sowohl das Erlebnis revolutionä-rer Menge als auch die Vorstellung einer unermesslichen, nivel-lierten Bevölkerung stellen indivi-duelle Existenzformen grundsätz-lich in Frage. Darstellung, Erfah-rung, Regulation und Reflexion der Masse sind deshalb zentrale Aufgaben des modernen Wis-sens, für deren Bewältigung Lite-ratur und Wissenschaft wichtige Beiträge geliefert haben. Michael Gampers Studie befasst sich mit der zentralen Rolle der Literatur bei der Etablierung der Masse als Objekt des Wissens und dessen imaginativer Gestaltung vom 18. bis ins 20. Jahrhun-dert. Besondere Aufmerksamkeit wird dabei dem Wechselverhält-nis mit den Wissenschaften, der Sozialstatistik, der Psychologie, der Soziologie und der Physik gewidmet.

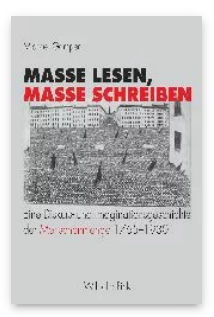

Pages: 582

Seiten

Language:

German

Subjects:

Cultural History,

Literature and

Cultural Studies

Publisher: Brill |

Fink

E-Book (PDF)

Released online:

29 Oct 2019

ISBN: 978-3-

8467-4436-9

List price

USD \$111.00

Hardback

Publication date:

23 May 2007

ISBN: 978-3-

7705-4436-3

List price

USD \$111.oo 
For more information see brill.com

Order information: Order online at brill.com +44330 333 0049 | customerservices@brill.com Submission information: brill.com/authors

Titles published by Brill | Fink, Brill | mentis or Brill | Schöningh: +49(o)715413279216| brill@brocom.de 